Research Article

\title{
Coupling of Agricultural Product Marketing and Agricultural Economic Development Based on Big Data Analysis and "Internet+"
}

\author{
Jing Xiao, ${ }^{1}$ Wenlan Wang $\mathbb{D}^{2},{ }^{2}$ and Sang-Bing Tsai $\mathbb{C}^{3}$ \\ ${ }^{1}$ Jinshan College, Fujian Agriculture and Forestry University, Fuzhou, Fujian 350002, China \\ ${ }^{2}$ School of Economics and Management, Fujian Agriculture and Forestry University, Fuzhou, Fujian 350002, China \\ ${ }^{3}$ Regional Green Economy Development Research Center, School of Business, WUYI University, Nanping, China
}

Correspondence should be addressed to Wenlan Wang; wzg916@163.com and Sang-Bing Tsai; sangbing@hotmail.com

Received 27 August 2021; Revised 22 September 2021; Accepted 30 September 2021; Published 18 October 2021

Academic Editor: Zhiyong Yu

Copyright (c) 2021 Jing Xiao et al. This is an open access article distributed under the Creative Commons Attribution License, which permits unrestricted use, distribution, and reproduction in any medium, provided the original work is properly cited.

In the era of "Internet+," the increase of agricultural products sales can be achieved by creating and joining e-commerce platforms. Most of the farmers in China are self-employed and cannot form an industrial scale. With the rise of "Internet+" background research, the combination of this technology and the marketing of agricultural products has become a new marketing model under the deep integration of different fields. Based on the marketing of products under the background of "Internet+" and using marketing theories, this paper reviews the development of marketing of agricultural products under the background of "Internet+," including the Internet infrastructure, the establishment of logistics system, the formation of branding, and the deep processing of agricultural products. The paper reviews the development of agricultural marketing under the background of "Internet+," including the Internet infrastructure, establishment of logistics system, branding, and deep processing of agricultural products. The marketing mode of agricultural products under the background of "Internet+" is proved, and the development of agricultural products marketing under the background of "Internet+" is discussed from various angles, and insights into how to improve it are proposed from five aspects. After excluding the influence of environmental factors through the improved threestage SE-DEA model, the mean value of TE of comprehensive efficiency of agricultural information allocation increases from 0.773 to 0.832 , the mean value of SE of scale efficiency increases from 0.844 to 0.9219 , and the mean value of PTE of pure technical efficiency adjusts from 0.9087 to 0.9058 . The mean value of pure technical efficiency (PTE) was adjusted from 0.9087 to 0.9058 . Compared with the parametric method, DEA does not require a specific production function to be set in advance, and it is also difficult to select a suitable production function in advance for complex problems.

\section{Introduction}

Despite the rapid level of economic development, the world still belongs to a large agricultural country. Compared with the development of other industries, the marketing level of our agricultural products is low and cannot become an important driving force of agricultural economic development [1]. The reason for this is that China's farmers lack a high level of cultural literacy and do not have the correct concept of network marketing. Although farmers have been very familiar with the Internet, they always do not know how to correctly apply it. For this reason, farmers should establish the correct concept of Internet marketing, strengthen their own understanding and application of the Internet, use the Internet as an important way to sell agricultural products, and no longer limit the sale of agricultural products to a specific region [2]. At this time, farmers need to innovate their concepts, take the first step of Internet marketing, open stores in e-commerce platforms, learn relevant Internet marketing knowledge, and improve the sales of agricultural products. Establishing a sound network infrastructure is an important way to improve the coverage of the Internet, and an important way to use the Internet for agricultural products sales [3]. 
Today, most rural areas have achieved full network coverage, but some areas with more backward economic development have not yet achieved full Internet coverage [4]. The sale of agricultural products in these areas still adopts the previous low-priced bulk purchase method. For example, some agricultural products that are not suitable for preservation often rot because they cannot be sold in time, bringing certain losses to farmers. For this reason, governments at all levels should increase the investment in network infrastructure construction and improve the coverage of the Internet by means of financial subsidies, etc., so that farmers can grasp market information in time to sell their agricultural products. Professional talents are an important factor in promoting the development of agricultural economy, and Internet talents play a greater role in the process of selling agricultural products [5]. Therefore, the government should increase the training of Internet talents, organize farmers to participate in Internet skills training during the agricultural leisure period, improve farmers' Internet knowledge and practical marketing operation ability, improve farmers' Internet literacy, and provide talents to support the Internet marketing of agricultural products so that they can create corresponding Internet marketing stores on the Internet platform, upload agricultural products regularly, strengthen communication with consumers, and promote the sales of agricultural products with good and high-quality services. In the background of the new era, the Internet is developing very rapidly and applied to many fields [6]. A small number of special agricultural products in the world have seized the opportunity to innovate the development mode of agricultural products, but there are still many local special agricultural products that follow the traditional marketing model and now no longer have strong competitiveness and advantages; the traditional promotion and marketing means of special agricultural products are in a marketing dilemma [7], but the increase of total government investment amount may bring the waste of agricultural information allocation input [8]. The specific environmental factors selected in this paper include gross per capita product, total government investment amount, and the number of new rural population with higher education, among which the increase of gross per capita product and the number of new rural population with higher education can drive the utilization rate of agricultural allocation input amount and save the cost of agricultural information resource allocation, but the increase of total government investment amount may bring the waste of agricultural information allocation input.

With the rapid development of the economy and the continuous innovation of Internet technology, the marketing mode of the world's agricultural products has undergone great changes in recent years. Some agricultural products with local characteristics have started to attract the attention of consumers outside the region, and promoting the development of special agricultural products will become an inevitable trend of economic development [9]. In this paper, we analyze the current situation of marketing of characteristic agricultural products under the background of "Internet+" and some of the difficulties faced at present, study the development history and marketing path of marketing of characteristic agricultural products, and explore the innovation mode of marketing of characteristic agricultural products so as to provide some reference for the marketing of characteristic agricultural products under the environment of high-speed development of Internet. However, due to the different realities in different places, the lag of various links from production and operation of agricultural products to consumer purchase, the traditional concept of marketing, compared with the marketing concept of "Internet+" agricultural products, has not been able to play the greatest superiority. The problems of agricultural products marketing under the background of "Internet+" studied in this paper include low coverage of Internet infrastructure, inadequate construction of logistics system, asymmetry of product marketing information, relatively late branding construction, and lack of marketing awareness under the background of "Internet+." In addition, we propose targeted marketing strategies under the background of "Internet+."

This has theoretical significance for the research of marketing strategies of agricultural products in different regions in the world at the present stage, and at the same time, due to the development of this study, each region can use different methods based on its own characteristics to conduct in-depth Internet marketing exploration for the special agricultural products in the region, which can also provide reference opinions for such research in different regions. Agricultural marketing refers to the marketing process of agricultural products, according to the subject-the operator-and the producer's independent dynamic behavior, coupled with interference factors, the targeted marketing activities, so as to meet the transformation of crops from goods to commodities of commercial properties, so that agricultural products are given commercial value, to meet the needs of society for agricultural products, so as to get more economic added value of a kind of activity. It is different from the traditional marketing, which is dominated by production conditions.

\section{Related Work}

The development of agricultural industry is inseparable from the marketing effect of agricultural products, which directly determines whether the overall industrial chain of agricultural products is well developed or not, and is also the embodiment of the marketing value of agricultural products [10]. The background of "Internet + " technology has developed with the rise of online shopping. This consumption channel chosen by consumers has accelerated the speed of commodity circulation, and also made the competition among merchants in various regions more transparent and fierce. Farmers should fully grasp the business opportunities, use the "Internet+" integration of technology platform for development, sales of their own agricultural products, so that the sales of agricultural products to improve. This is not only the result of integrating modern technology, but also the sublimation of modern marketing concept [11]. The added value of agricultural products can be actively 
increased, and the marketing efficiency of production and distribution can reach a level unmatched by the traditional marketing mode so that the production and operation methods of agricultural products can be improved and the market share of different agricultural products can be increased [12]. The accelerated development of the agricultural industry is not only conducive to improving the income and living standards of the majority of farmers, but also has practical significance in reducing the unbalanced economy of various regions in this context.

At present, the research on the development of agricultural marketing under the perspective of "Internet + " is in the initial stage at home and abroad, and certain results have been achieved. The current situation of online marketing of agricultural products in the world and the experience of online marketing of agricultural products in other countries are fully integrated [13]. In addition, researchers also discuss the logistics and distribution system of agricultural products marketing and follow the development of the Internet, in order to promote the rapid development of the world's agricultural products online marketing [14]. At the same time, in the context of the "Internet+" era, scholars have analyzed the impact of the "Internet+" model on the world's traditional agricultural marketing model and the domestic market economy [15]. The research results of the scholars have the characteristics of being close to the actual and practical sources for the online marketing of agricultural products in the world, which are more foreseeable and pioneering for the development of agricultural marketing under the premise of "Internet+", and also provide more accurate reference and reference for the marketing of agricultural products [16]. Our government departments at all levels also actively support the marketing of agricultural products, and continuously guide and promote the development of the agricultural industry chain. However, due to the vast territory, the natural resources and production conditions of agricultural products vary from place to place, so the characteristics of agricultural products vary from place to place. However, the quality of agricultural products in some regions is good, but there is no good marketing strategy to expand their popularity, resulting in the mismatch between production and marketing [17]. There is an urgent need to study and set up a reasonable marketing model to broaden the sales channels of agricultural products. It is necessary to integrate the regional and seasonal factors to promote the economic prosperity of agricultural products under the unique natural resources of each region and to upgrade the industrial chain of agricultural products as soon as possible.

In recent years, under the guidance of the relevant departments of logistics system construction, the state has introduced a series of development plans to accelerate the construction of logistics facilities such as storage, transportation, and processing of agricultural products in the world and to establish a sound logistics service system [18]. The development plan requires emphasis on providing guarantee for the improvement of logistics marketing efficiency of agricultural products in the world. However, regarding the logistics system of agricultural products in some areas, especially in Guangxi, Shanxi, Gansu, and other agricultural products planted in a wide area, but for the weak economic base of the part, whether from the equipment, technology, or labor, frozen storage and other aspects, there is still room for improvement. Undertaking the key logistics system of the circulation of important agricultural products still needs to improve and enhance the part of the construction [19]. This will directly affect the damage rate of agricultural products, especially fresh products [20]. The different natural resources in each region have given birth to excellent crop varieties [21]. Whether it is vegetables, fruits, or rice, all of them have geographical advantages, and some of them have already occupied a certain position in consumers' heart, such as Jiangsu Yangshan peach and Shandong chestnut, which have been awarded with geographical indications. However, the marketing method of brand establishment and maintenance is less, and at present, agricultural products still take the geographical location of each place as the main symbol, and the formation and development of brands are not synchronized among different agricultural products producers.

\section{3. "Internet+" Perspective of Agricultural Marketing Information Resource Allocation Marketing Efficiency}

3.1. Nonparametric Analysis of the Efficiency of Configuration Marketing. When studying the marketing efficiency problem of agricultural information resource utilization, there are two general analysis methods, nonparametric analysis (DEA) and parametric analysis (SFA), each of which has advantages and disadvantages in use. The parametric analysis method (SFA) has a greater advantage in dealing with the marketing efficiency problem of multiple inputs corresponding to one output [22-24]. However, agricultural information resource allocation marketing efficiency problems generally need to solve the correspondence between multiple inputs and multiple outputs, which cannot be measured simply by using the parametric analysis method. Compared with the parametric method, DEA does not require a specific production function to be set in advance, and it is also difficult to select a suitable production function in advance for complex problems and directly apply the output and input data of agricultural information resource allocation decision subjects to the DEA method; it can measure the relative marketing efficiency values among decision units, eliminating the adverse effects of many human subjective factors.

DEA analysis, whose full name is Data Envelopment Analysis, is a nonparametric analysis method studied through the integrated use of mathematical statistics, management science, and operations research, as shown in Figure 1. The method can use the results of the evaluation of the marketing efficiency of multiple-output and multipleinput systems to represent the marketing efficiency values of agricultural information resources allocation, and also to analyze the relative marketing efficiency values among the decision units. Before determining the input-output 
effectiveness, the production frontier surface is first found, which can be determined using linear programming. Then, each decision unit is mapped, and the relative effectiveness of each decision unit is evaluated by comparing the distance between each decision unit and the production frontier surface (see Figure 1).

The scale of the input and output indicators also does not affect the measurement results, so DEA is a good method to judge the validity between multiple inputs and multiple outputs. Assuming that there are $n$ decision units, each decision unit has $s$ different outputs and $m$ different inputs, the input of the ith input and the $j$ th decision unit can be represented by $x_{i}$, and the output of the $r$ th output and the $j$ th decision unit can be represented by $y_{i}$, the basic inputoriented DEA analysis model (CCR) is

$$
\begin{aligned}
V_{d} & =A^{\mathrm{min}}, \\
\sum_{i=1}^{n} V_{i} x_{i} & =\beta_{i}, \\
\sum_{i=1}^{n} V_{i} y_{i} & =\alpha_{i} .
\end{aligned}
$$

Andersen (1993) created the SE-DEA model of supermarketing efficiency. Compared with the traditional DEA model, SE-DEA uses a reference set that does not include the evaluated decision units; that is, the inputs and outputs of the evaluated decision units are expressed by linear combinations of the inputs and outputs of other decision units so that the evaluation results can still be measured with increasing returns to scale. At the same time, SE-DEA can rank or classify all decision units that satisfy the effective production frontier. Coupled with the ability to redundantly analyze slack variables, specific information on specific resources with high marketing efficiency can be identified in cities with high-resource utilization, providing more effective information to guide resource allocation in other cities. The supermarketing efficiency SE-DEA model is shown as follows:

$$
\begin{aligned}
\sum_{i=1}^{n} V_{i} y_{i}-s^{+} & =\alpha_{i o}, \\
\sum_{i=1}^{n} V_{i} x_{i}-s^{-} & =\beta_{i o}, \\
V_{d} & =\alpha_{i}-\beta_{i} .
\end{aligned}
$$

The construction of the evaluation index system of any research object requires scientific basis and systematic and thorough consideration. The application theory of agricultural information science recognized by the industry is the theoretical basis for constructing evaluation indexes of agricultural information resource allocation and marketing efficiency. The construction of agricultural information resource allocation indexes should not only meet the logic of agricultural information science application, but also fully consider the development of agricultural information technology and truly and accurately reflect the fundamental problem of marketing efficiency differences in various regions. Agricultural information resource allocation involves multiple inputs and outputs, and is a complex systemic issue that requires coordinated and common assistance from various aspects such as financial investment in agricultural informatization, human and material investment in agricultural operation, agricultural information technology development and application, and agricultural information infrastructure construction. Research on the efficiency of agricultural information resources configuration marketing should not only consider the configuration and utilization of local municipalities, but also grasp the important guiding policies of agricultural informatization to improve the accuracy of configuration and utilization measurement.

3.2. Marketing of Agricultural Products. Agricultural marketing refers to the marketing process of agricultural products, according to the subject-the operator-and the producer's independent dynamic behavior, coupled with interference factors, the targeted marketing activities, so as to meet the transformation of crops from goods to commodities of commercial properties, so that agricultural products are given commercial value, to meet the needs of society for agricultural products, so as to get more economic added value of a kind of activity. It is different from the traditional marketing, which is dominated by production conditions. Marketing of agricultural products also refers to a marketing method in which agricultural producers and operators ensure the efficient service of the whole industrial chain based on the market law and the characteristics of vegetables and fruits produced in the specific situation and the different local regions and seasons, so that the sales of agricultural products can be increased. This is a marketing method to grasp the overall demand of consumers and to meet the potential orientation of the market, actively seek the sales effect and cope with anti-interference.

Agricultural information resource allocation assessment indicators need to be as comprehensive as possible under the premise of feasibility in order to constitute a basic and operable evaluation indicator system. It is not the case that the more indicators selected to assess the allocation marketing efficiency of agricultural information resources, the better; too many indicators are likely to make the system overfitted and the calculated results to guide the operability value to be lower, as shown in Figure 2. In the process of configuration marketing efficiency evaluation, some factors are incidental, small amount, short duration, and no important influence, and these factors can be blocked out. At the same time, the evaluation indexes selected in this paper need to be tested in practice, and their operability can be corroborated by practical cases. The development of agricultural informatization has not stopped since the 1980s, but with the adjustment of agricultural informatization policy, innovation of information technology, and change of agricultural economic development ideas, the allocation of agricultural information resources needs to be adjusted in different ways according to the current situation. 


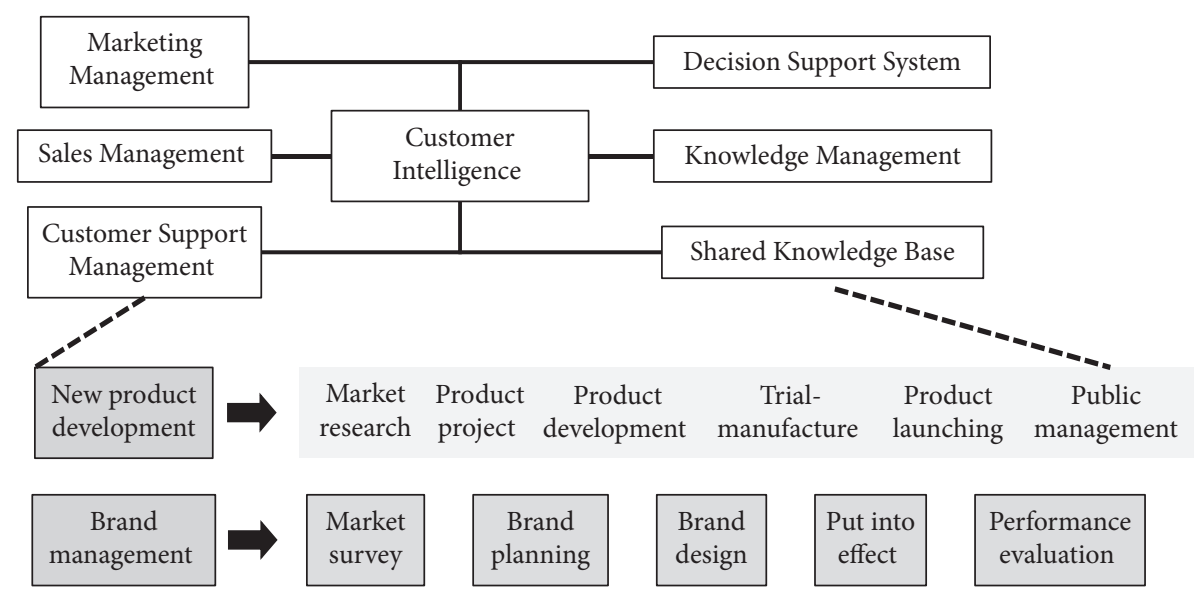

FIgURE 1: Marketing analysis theory based on mathematical statistics.

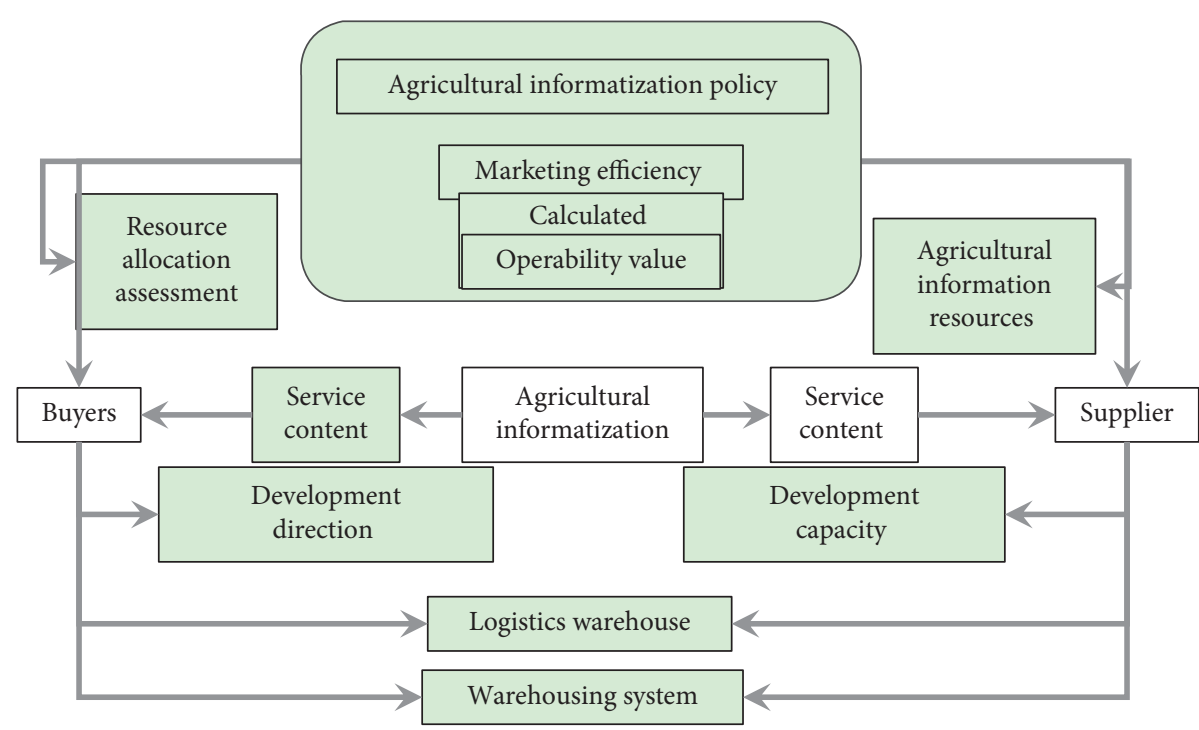

FIgURE 2: Indicators of marketing efficiency of agricultural information resources allocation.

Agricultural information resource allocation evaluation indexes need to be adjusted at different stages according to the development direction and development capacity of informatization, and only in this way can we continuously improve the efficiency of agricultural information resource allocation and marketing, and more practically and feasibly contribute to the development of agricultural informatization (see Figure 2).

The concept of "Internet+" is not just a simple superimposition of concepts, nor is it a superficial association between agricultural marketing and "Internet+," but a deep organic integration of "Internet+" with the overall. It is a deep organic integration of "Internet+" and overall agricultural marketing, creating more scientific and efficient modern agricultural marketing means and methods. It is the integration of the traditional agricultural market into the new agricultural marketing methods, and proposes a reasonable, fast, and shared new marketing approach. It can change the traditional agricultural marketing means, pursue the development of production and market expansion more, quickly enhance the new agricultural marketing methods, and promote the agricultural industry to promote the steady progress of modern agriculture. The combination of "Internet+" and agricultural marketing is divided into different stages to carry out. In the primary stage, we can simply integrate the platform sales technology of e-commerce into the marketing of agricultural products, reflecting the characteristics of its network sales; in the second stage, the concept of the Internet will be fully penetrated into the marketing of agricultural products; in the third stage, the stage of comprehensive integration, more detailed 
guidance on the whole industrial chain of agricultural products, and the service concept of consumers, to realize the integrated development of modern agriculture.

\section{Results and Analysis}

In order to analyze in more detail the main influencing factors of agricultural information resource allocation marketing efficiency in 10 prefecture-level cities, we combine the evaluation indexes of agricultural information resource allocation marketing efficiency established in the previous chapter based on scientific, operability, and dynamics, and establish the explanatory variables of the influencing factors of Tobit model, including the number of cell phones in 100 rural residents' households, the population coverage rate of digital TV in rural residents, the number of rural residents' 100 Internet bandwidth access, the number of agricultural information-related websites, and the number of cultural stations for rural residents, as shown in Figure 3. The agricultural sector has also formed a special website for the sale of agricultural products. The data in this chapter are also derived from Internet information. At present, although the deep processing of agricultural products has attracted the attention of various production and processing enterprises, the systematization required is high, the software and hardware equipment for professional production and processing are not well implemented, and the unfavorable factors in the processing process may also affect the quality of agricultural products. To a certain extent, this will pull the marketing system and competitiveness of agricultural products to a weaker side. In the field of processing, in terms of the current situation of deep processing, the industrial chain and market radiation ability are relatively weak, which will affect the size of the added value of agricultural products. The self-built enterprise refers to the self-built platform of the agricultural production enterprises based on their production technology and marketing methods. By perfecting their own sales chain, they can develop and cooperate from their own platform and sell agricultural products. For example, Gansu Jurong Company has built its own "Jurong.com," and Jiangxi Nanfeng Fruit Trade has built its own e-commerce platform to carry out one-stop services. Some agricultural production bases also build platforms for agricultural products, but such enterprises build their own way, mainly by commissioning other large enterprises to complete (see Figure 3).

Through Tobit regression analysis, as shown in Figure 4, the degree of influence of these five variables on the allocation marketing efficiency of agricultural information resources was measured, among which the number of cell phones per 100 rural residents and the amount of Internet bandwidth access per 100 rural residents were significant below the level of 0.01 (Prob. $<0.01$ ), and the degree of influence of the remaining items was measured not very significant, but also had a correspondingly positive effect on the allocation marketing. The remaining items are not significant, but they also have a positive effect on the allocation of marketing efficiency. Among the five variables mentioned above, the number of cell phones and the amount

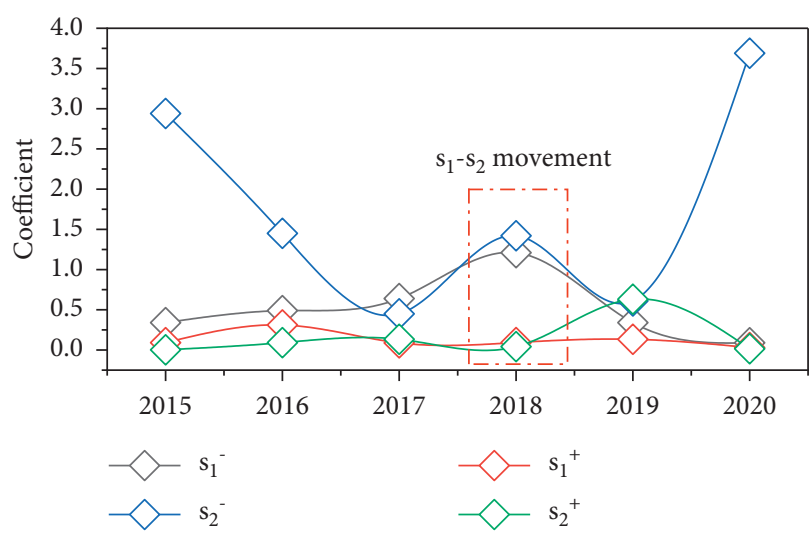

FIgURE 3: Impact of variables in Tobit model.

of Internet bandwidth access are the most important ones in terms of allocative marketing efficiency. Government guidance refers to the provision of enterprise services such as information-based production and marketing of the whole industry chain to the marketing platform of agricultural products in the mode of government services. The agricultural sector has also formed a special website for the sale of agricultural products. It can help and support the small and micro agricultural products production enterprises in each region to occupy a favorable position in the operation and marketing activities of agricultural products. This kind of platform is a public welfare project of the government, and the cost is also borne by the government. At present, the more commonly used authoritative platforms include "National Public Service Platform for Agricultural Products Business Information," "Planting and Breeding Agricultural Products Traceability System Platform," and "National Public Information Platform for Agricultural Products Quality and Safety." Through the discovery of invisible customer groups, more and more people understand agricultural products. Farmers can make use of various modes of the Internet to advertise their agricultural products. By creating web pages dedicated to agricultural products, fictional animated stories about agricultural products, designing special icons of agricultural products, etc., and adding pictures, videos, and relevant product proofs to them to make consumers understand more clearly and minimize the problems arising from asymmetric information about agricultural products between farmers and consumers. The promotion of agricultural product information and outstanding sales volume cannot be achieved without the Internet (see Figure 4).

The coefficients of factors such as the number of cell phones per 100 rural households, Internet bandwidth per 100 rural households, digital TV population coverage of rural residents, and the number of agricultural information-related websites are positive, indicating that agricultural information infrastructure construction factors have a significant positive effect on information allocation marketing efficiency in general, which is consistent with the guiding goal of promoting information service system construction in agricultural informatization, and the allocation of agricultural information resources should be adhered to. Quantity and quality should be given equal 


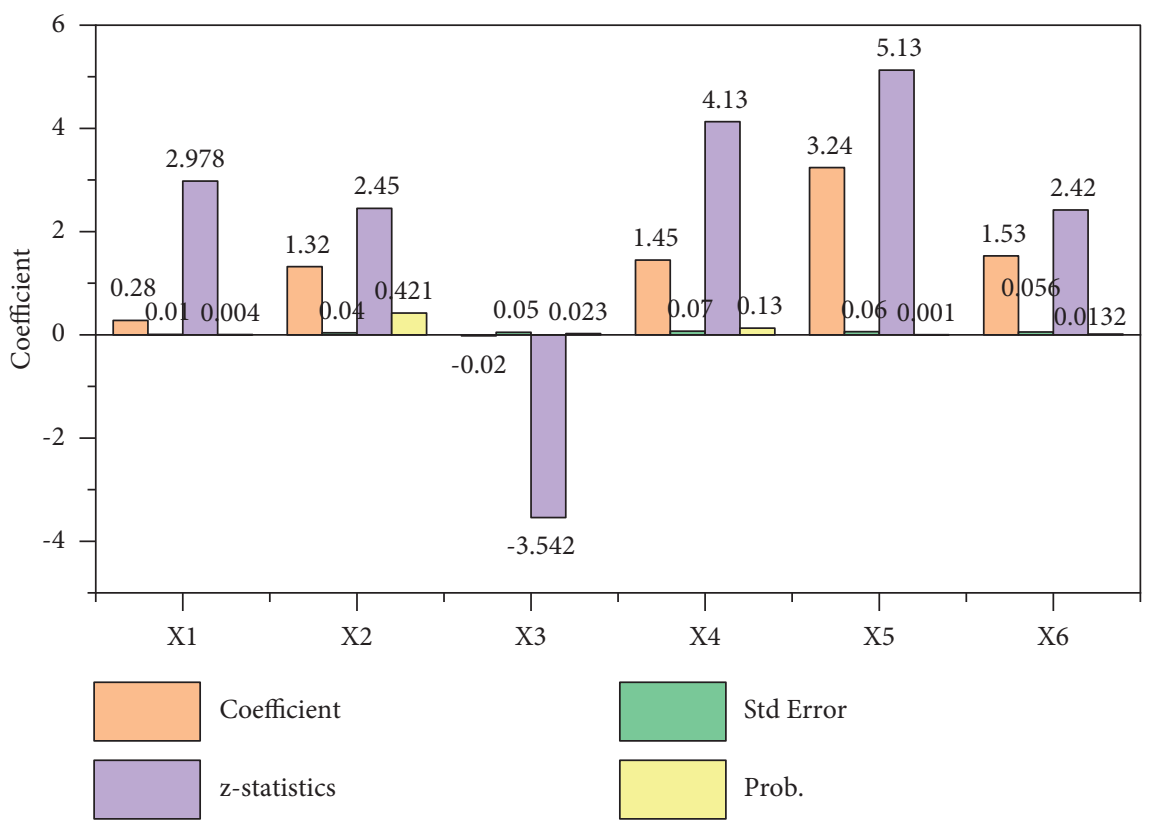

Figure 4: Results of Tobit model.

importance to development, and the construction of information service system needs to be vigorously promoted by government-led efforts to help support the development of enterprises, talents, and technologies that carry information services, and solve the problems of coverage, acceptance and the last mile in information services. Each increase of 1 unit in the number of cell phones will increase the value of comprehensive marketing efficiency of agricultural information resource allocation by 0.01 units, and each increase of 1 unit in the amount of Internet bandwidth access will increase the value of comprehensive marketing efficiency of agricultural information resource allocation by 0.04 units, as shown in Figure 5. Taken together, the increase in the amount of these positively correlated inputs will continue to promote the improvement of comprehensive marketing efficiency until a certain optimal scale level is achieved. The continuous development of e-commerce has driven a change in the marketing model of agricultural products to a certain proportion of online sales. Farmers are flocking to participate in online sales, tapping more invisible customers and giving agricultural products access to a wider sales market. Because the price of the same product is lower and more affordable in offline stores and online platforms than in online platforms, it is more in line with consumer demand. Therefore, in the context of "Internet+," the pricing on the online platform also limits the sales volume of agricultural products. With the decline in net income, farmers have improved their production technology by innovating in terms of planting techniques in order not to lose money. In response, the fierce competitive environment is also conducive to stimulating related companies to play the game, thus leading to the progress of agriculture as a whole (see Figure 5).

The Tobit measurement coefficient of the number of rural residential cultural stations on the comprehensive marketing efficiency is negative, but the importance of rural residential cultural stations in promoting the marketing

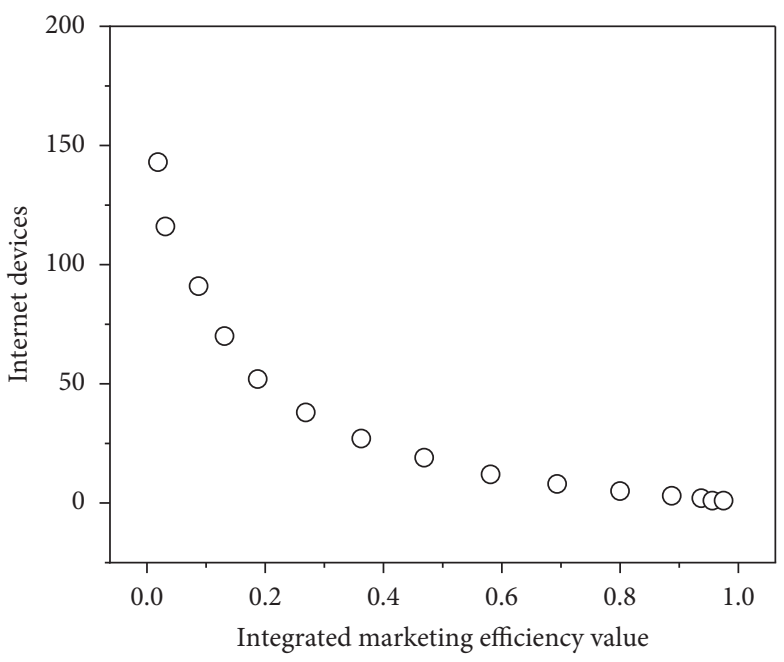

FIGURE 5: Correlation between the integrated marketing efficiency value of agricultural information resource allocation and the number of internet devices.

efficiency of agricultural information resource allocation cannot be denied in its entirety, nor is it one-sided to say that by reducing the number of rural residential cultural stations, the comprehensive marketing efficiency of 0.0004 units can be improved, as shown in Figure 6. The reason for this is that the focus of the current use of cultural stations for rural residents has shifted, and they may no longer be single agricultural information and cultural stations, but may also be used for information dissemination in other industries and for entertainment in rural areas. "Visual agriculture" refers to the use of the Internet, the Internet of Things, and modern video technology to show consumers the growth process of crops or livestock, so that they can buy quality products with confidence, that is, a kind of visible 


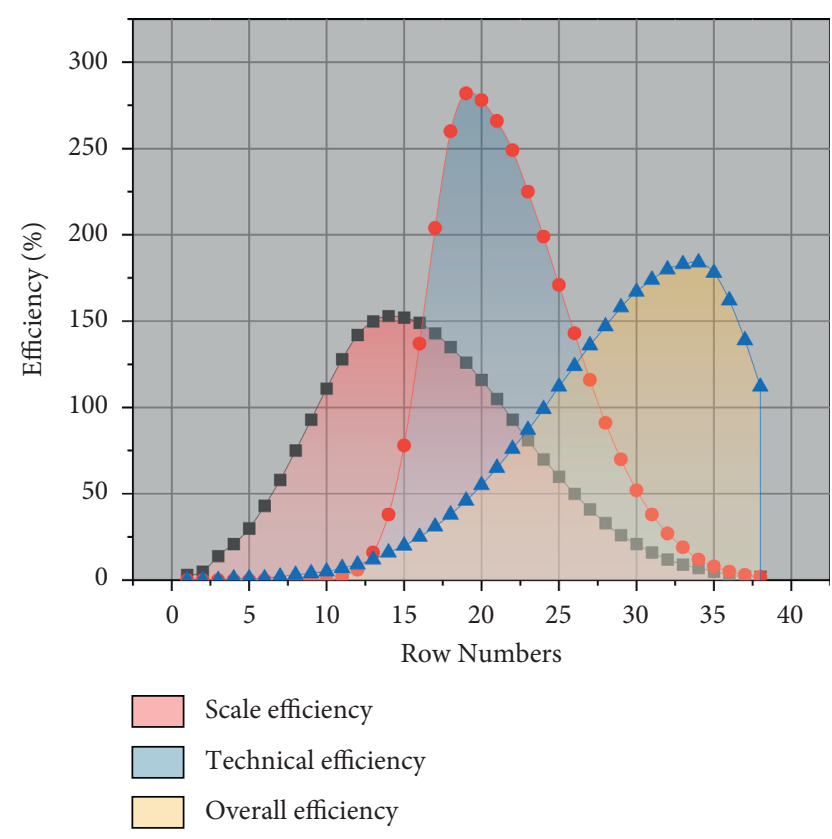

Figure 6: Effect of the number of cultural stations for rural residents on the efficiency of integrated marketing.

agriculture. This model is to let farmers reveal all their planting and operating behaviors in the sunlight, so that farmers' management can be further improved and bad behaviors can be restrained. Agricultural products can be advertised by hiring a professional filming team and broadcasted in commercial plazas with high traffic flow as well as on various Internet media. Consumers can view the vegetables and fruits planted in the base through Internet video, and also enjoy the joy of raising livestock in the cloud. No matter when and where they are, they can see the growth dynamics of crops or livestock, fertilization, and feeding through video or pictures, so that they can buy healthy products without additives and pollution without worries (see Figure 6).

Because most consumers learn about the agricultural products they need on e-commerce or Internet platforms, more and more farmers are leaving the opportunity to showcase and promote their agricultural products to e-commerce and Internet platforms. In this way, consumers can buy the agricultural products they need without having to leave home. The Ali platform has opened up new sales channels for agricultural products with e-commerce to the countryside, creating a village e-commerce system in collaboration with relevant departments, deepening the field of agricultural products e-commerce, and solving the problem of difficult sales and transportation of agricultural products. The most important thing for the development of agricultural products on the Internet is the means of network marketing, the Internet is developing rapidly, but the technology is still immature, and there is a serious lack of marketing talents in network; various relevant departments should increase rural education capital, improve farmers' awareness of agricultural production and marketing efficiency, provide farmers with knowledge and technical guidance, so as to enhance farmers' network, business and marketing management techniques, cultivate the technology engaged in agricultural products network Talent, to provide a strong guarantee for the world's agricultural products network marketing. At the same time, the improved DEA model also conducts superefficiency analysis for cities in the efficiency frontier side of agricultural information resource allocation and provides a more in-depth interpretation of each city's decision-making unit, as shown in Figure 7, in which the superefficiency value of City reaches 1.6896 , and rank 2 nd to $3 \mathrm{rd}$, and the superefficiency analysis can indicate that the financial investment, agricultural information service input, and agricultural information. The superefficiency analysis can show that these four cities can still maintain their relative efficiency by increasing their financial input, agricultural information service input, and agricultural information construction input according to the ratio of $68.96 \%, 39.86 \%, 25.38 \%$, and $21.75 \%$ (see Figure 7).

With the scale marketing efficiency SE and pure technical marketing efficiency PTE as the axes and the full evaluation value $(0.9058,0.9219)$ as the critical point, four types of cities are divided to show the allocation of agricultural information resources in northern Shaanxi, southern Shaanxi, and central, as shown in Figure 8. The first category in the upper right corner of the figure is the "double-high" cities with scale marketing efficiency and pure technical marketing efficiency above the critical value, including Xi'an, Yulin, Yan'an, and Tongchuan, which have less room to improve the marketing efficiency of agricultural information resource allocation; the second category is the second quadrant with the critical point as the origin, which has high-scale marketing efficiency but low pure technical marketing efficiency. This type of cities includes Xianyang and Weinan, with PTEs of 0.739 and 0.801 , respectively, which have more room for improvement; the third category is the third quadrant with the origin of the critical point, where the scale marketing efficiency and the pure technical marketing efficiency are double-bottom cities, such as Ankang, which need to be adjusted from the configuration scale and technical management level in order to improve comprehensively; the fourth category is the last quadrant with the origin of the critical point, where the scale marketing efficiency is high but the technical marketing efficiency is low. High-low cities with high pure technical marketing efficiency but bottom scale marketing efficiency, including Baoji, Hanzhong, and Shangluo, these cities should improve in the configuration scale strategy, increase the coverage of agricultural informatization, and improve in the scale efficiency of agricultural information resource allocation (see Figure 8).

The efficiency values estimated by the BCC model in the improved DEA method belong to discrete distribution data truncated between 0 and 1 . If the efficiency values of the improved three-stage DEA are interpreted by regression using the traditional OLS least squares method, they are prone to large biases in the estimation of agricultural information input parameters. The Tobit model is also an extension of the traditional Probit model, in which the explanatory quantity can be "unrestricted" when the value of the explanatory variable is greater than 0 . This paper 


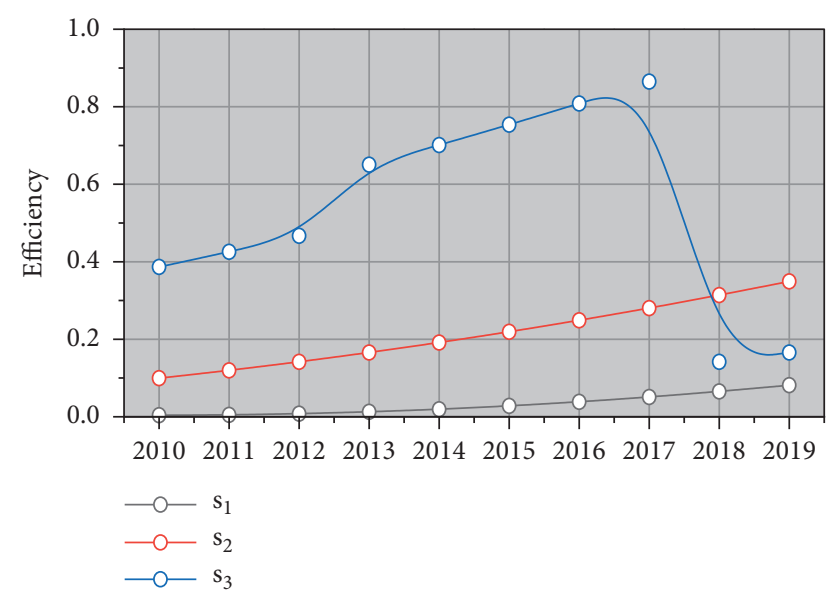

FIGURE 7: Variation of the relationship between entities $\mathrm{E}$ and R.

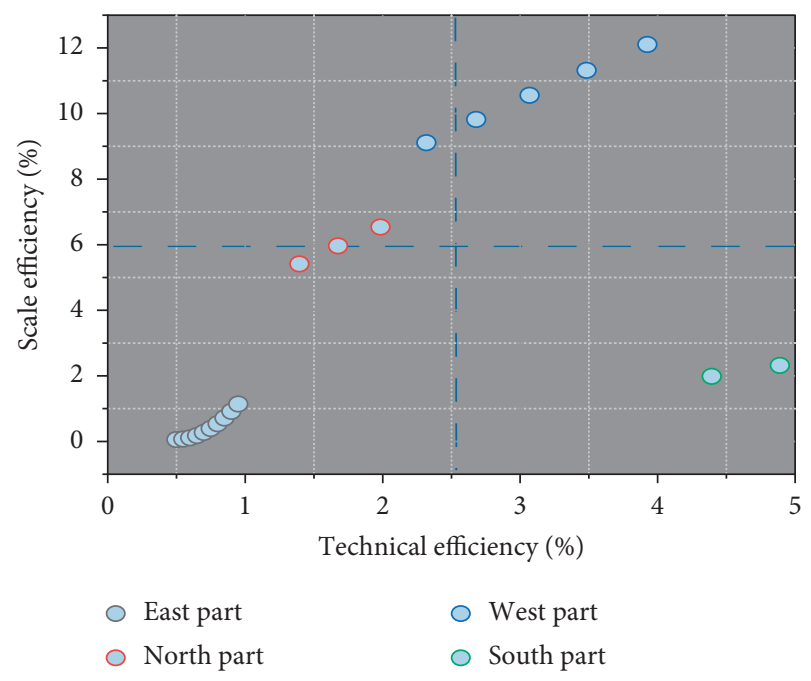

FIgURE 8: Configuration efficiency distribution quadrant.

constructs a Tobit regression model to analyze the impact of agricultural information resource allocation efficiency based on the input parameters of agricultural information resource allocation. The specific environmental factors selected in this paper include gross per capita product, total government investment amount, and the number of new rural population with higher education, among which the increase of gross per capita product and the number of new rural population with higher education can drive the utilization rate of agricultural allocation input amount and save the cost of agricultural information resource allocation, but the increase of total government investment amount may bring the waste of agricultural information allocation input. We hope that we can refer to the positive and negative correlation reasons of specific environmental factors to adjust and help to improve the allocation efficiency more.

\section{Conclusion}

This paper reviews the development of agricultural marketing under the background of "Internet+," including the
Internet infrastructure, the establishment of logistics system, branding, and deep processing of agricultural products. The marketing mode of agricultural products under the background of "Internet + " is proved, and the ways of agricultural marketing development under the background of "Internet+" are discussed from various angles, and insights into how to improve them are proposed from five aspects. The combination of "Internet+" background and agricultural marketing is of great practical significance to enhance the logistics and brand reputation of agricultural products, strengthen the construction of network platform infrastructure, and further improve the system of agricultural marketing in the world. Based on the Tobit model, this paper establishes a detailed analysis of the positive and negative effects of input factors on agricultural allocation efficiency, such as the number of cell phones per 100 rural households, the population coverage rate of digital TV for rural residents, the amount of Internet bandwidth access per 100 rural households, the number of agricultural information-related websites, and the number of cultural stations for rural residents. Comprehensive Tobit model measurement results analysis, cell phone, Internet bandwidth access, and other factors have a positive effect on the comprehensive efficiency; the role of the number of cultural stations for rural residents has a negative effect on the comprehensive efficiency. The results of the traditional DEA model measuring the efficiency of agricultural information resource allocation have large errors. After excluding the influence of environmental factors through the improved three-stage SEDEA model, the mean value of TE of agricultural information allocation increases from 0.773 to 0.832 , the mean value of SE of scale efficiency increases from 0.844 to 0.9219 , and the mean value of PTE of pure technical efficiency increases from 0.9087 . In the future, we would improve their production technology by innovating in terms of planting techniques in order not to lose money.

\section{Data Availability}

The data used to support the findings of this study are included within the article.

\section{Conflicts of Interest}

The authors declare that they have no conflicts of interest.

\section{References}

[1] H. Schaak and O. Mußhoff, "Understanding the adoption of grazing practices in German dairy farming," Agricultural Systems, vol. 165, pp. 230-239, 2018.

[2] R. Stellian and J. P. Danna-Buitrago, "Colombian agricultural product competitiveness under the free trade agreement with the United States: analysis of the comparative advantages," CEPAL Review, vol. 2017, no. 122, pp. 127-149, 2018.

[3] R. Harder, R. Wielemaker, T. A. Larsen, G. Zeeman, and G. Öberg, "Recycling nutrients contained in human excreta to agriculture: pathways, processes, and products," Critical Reviews in Environmental Science and Technology, vol. 49, no. 8, pp. 695-743, 2019. 
[4] R. Ghisi, T. Vamerali, and S. Manzetti, "Accumulation of perfluorinated alkyl substances (PFAS) in agricultural plants: a review," Environmental Research, vol. 169, pp. 326-341, 2019.

[5] A. Bhagwat, "Agricultural product marketing based on ratings and reviews (APMRR)," International Journal for Research in Applied Science and Engineering Technology, vol. 7, no. 5, pp. 1548-1554, 2019.

[6] F. Hadi and Y. Diana, "Penerapan UML sebagai alat perancang website dinas pertanian kota payakumbuh," Indonesian Journal of Computer Science, vol. 8, no. 1, pp. 11-21, 2019.

[7] P. Teluguntla, P. S. Thenkabail, A. Oliphant et al., "A $30 \mathrm{~m}$ landsat-derived cropland extent product of Australia and China using random forest machine learning algorithm on google earth engine cloud computing platform," ISPRS Journal of Photogrammetry and Remote Sensing, vol. 144, pp. 325-340, 2018.

[8] U. L. Nkeiruka and T. I. Umar, "Commodity marketing and services systems' relationship with spacio-economic interactions in Akure city and its' inner towns and villages," Journal of Environment and Earth Science, vol. 8, no. 8, pp. 55-65, 2018.

[9] A. M. Bondarenko, E. I. Lipkovich, and L. S. Kachanova, "Control of technological processes of organic fertilizers application as a tool to ensure food safety," Journal of Environmental Management and Tourism, vol. 9, no. 1, pp. 5-11, 2018.

[10] C. Wang and P. Jiang, "Farmers' willingness to participate in agricultural product safety cogovernance and self-governance in Jiangsu, China: a gender perspective," Journal of Food Protection, vol. 83, no. 5, pp. 736-744, 2020.

[11] S. Zurinani, N. Rodiyah, N. Rodiyah, D. T. Prastyo, and M. Y. A. Zuhri, "Development strategy of brau edufarm tourism in batu," Journal of Indonesian Tourism and Development Studies, vol. 7, no. 2, pp. 100-110, 2019.

[12] G. W. Williams, O. Capps, and D. Hanselka, "U.S. National economic contribution of generic food and agricultural product advertising," Journal of International Food \& Agribusiness Marketing, vol. 30, no. 2, pp. 191-210, 2018.

[13] M. Comi, "Other agricultures of scale: social and environmental insights from Yakima valley hop growers," Journal of Rural Studies, vol. 80, pp. 543-552, 2020.

[14] P. A. Mbum and I. G. Ederewhevbe, "Economic recovery, growth paradox and agricultural product marketing in Nigeria," Lwati: A Journal of Contemporary Research, vol. 16, no. 3, pp. 125-148, 2019.

[15] A. Syahza, E. Savitri, B. Asmit, and G. Meiwanda, "Small-scale agricultural product marketing innovation through BUMDes and MSMEs empowerment in coastal areas," Management Science Letters, vol. 11, no. 8, pp. 2291-2300, 2021.

[16] C. B. D. P. Mahardika, W. Y. Pello, and M. Pallo, "Performa usaha kemitraan ayam ras pedaging," Partnerberatung, vol. 25, no. 1, pp. 1270-1281, 2020.

[17] J.-F. Li and Z.-X. Wang, "Research on coordination of multiproduct "agricultural super-docking" supply chain," Procedia Manufacturing, vol. 30, pp. 560-566, 2019.

[18] F. Bantis, S. Smirnakou, T. Ouzounis, A. Koukounaras, N. Ntagkas, and K. Radoglou, "Current status and recent achievements in the field of horticulture with the use of lightemitting diodes (LEDs)," Scientia Horticulturae, vol. 235, pp. 437-451, 2018.

[19] I. G. Ushachev, V. V. Maslova, and V. S. Chekalin, "Import substitution and ensuring food security of Russia," Vegetable Crops of Russia, vol. 2, no. 2, pp. 3-8, 2019.
[20] J. Guo, Y. Bao, and M. Wang, "Steel slag in China: treatment, recycling, and management," Waste Management, vol. 78, pp. 318-330, 2018.

[21] C. Jinbo, Z. Yu, and A. Lam, "Research on monitoring platform of agricultural product circulation efficiency supported by cloud computing," Wireless Personal Communications, vol. 102, no. 4, pp. 3573-3587, 2018.

[22] H. R. Shim and B. G. Kim, "The effect of customer value on user satisfaction with dialogue characteristics of apple's intelligent agent siri," Journal of Organizational and End User Computing, vol. 32, no. 1, pp. 62-74, 2020.

[23] M. Zaher, A. Shehab, M. Elhoseny, and F. F. Farahat, "Unsupervised model for detecting plagiarism in internet-based handwritten Arabic documents," Journal of Organizational and End User Computing, vol. 32, no. 2, pp. 42-66, 2020.

[24] S. F. Verkijika, "Assessing the role of simplicity in the continuous use of mobile apps," Journal of Organizational and End User Computing, vol. 32, no. 4, pp. 26-42, 2020. 